\title{
The Higher The Quality Of Teaching The Higher The Quality Of Education
}

Naveed Sultana, AIOU, Pakistan

Muhammad Imran Yousuf, PMAS-Arid Agriculture University, Pakistan

Muhammad Naseer Ud Din, KUST, Pakistan

Sajid Rehman, UIER, Rawalpindi, Pakistan

\begin{abstract}
The higher education plays as leadership role in the system of education. Quality education can ensure security, welfare and prosperity of a nation. The key factors influencing the quality of higher education is the quality of faculty, curriculum standards, technological infrastructure available, research environment, accreditation regime, administrative policies, financing, evaluation and good governance. The main objectives of the study were (1) To evaluate the indicators of good teaching. (2) To examine the institutional policies for valuing the teaching. (3) To examine the contribution of teaching towards professional development of teachers. (4) To find out institutional efforts for enhancing the professional development of teachers. For study purposes five federal universities of Islamabad were taken and their faculties were included in the population. Twenty teachers of each university were taken as the sample of the study. This sample was selected with the help of the students from each department. As students are considered tougher evaluators of the teachers so the selection of the good teachers was completed on the basis of the five common competencies such as competencies related to subject and subject area teaching, competencies related to teaching and learning, competencies in research work and competencies related to professional behaviour. This survey type study was conducted through a questionnaire. The study concluded that good teaching does not pay any benefit to teachers except self-satisfaction and also finding that the requirements for quality teaching are not available in universities. The present study recommends the higher quality of teaching may be ranked and recognized at local, national and international level.
\end{abstract}

\section{INTRODUCTION}

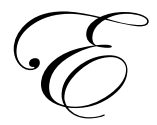

ducation is considered as instrument of change, whereas change is happening quicker than older times. Quality education can ensure security, welfare and prosperity of a nation. The quality of education is assessed through the quality of curriculum, students, teachers, teaching methods, governance, financing, evaluation and linkage with other apex institutions. The most important out of these factors is the faculty.

The quality of any education system depends upon the quality of higher education. According to the Barnett (1994) higher education as the production of qualified manpower; higher education as training for a research career; higher education as the efficient management of teaching provisions; higher education as a matter of extending life chances. Transformation of our institutions of higher education into world class seats of learning, equipped to foster high quality education, scholarship and research, to produce enlightened citizens with strong moral and ethical values that build a tolerant and pluralistic society rooted in the culture of Pakistan (Govt. of Pakistan, 2002).

Quality in higher education is multidimensional concept, which should embrace all its functions, activities, teaching and academic programmes, research and scholarship, staffing, students, building, facilities, equipment, services to the community and the academic environment (UNESCO.1998). The question of equality is directly related to the quality of teachers. The teacher is at the heart of the educational process. It is extremely important that he/she should be professionally competent and dedicated to his/her profession. A university teacher is more than a 
teacher of his/her subjects, he/she should be a powerful influence for enlightenment, stability, good conduct and national cohesion. (Mc Carty, 2003).

In higher education, university teachers play an effective role to understand and to improve the teaching \& learning process (Zaman, 1998). Teaching means to help somebody to learn something by giving information of it. Imparting instructions or guiding the students in institutions is called "teaching". In wider perspective it implies the interaction between the teachers and the taught, preparation and planning of the lesson, collecting necessary "teaching aids" and also such activities as evaluation of the instruction and communication (Misra, 2002).

University teachers play a basic and dynamic role in an educational system. It is said that good performance of students depends upon effective teaching of their teachers. One of the most difficult problems in educational research is that of recognizing the teacher's effectiveness i.e. discriminating between more effective teachers and less effective teachers (Coleman, 1998).

Effective teaching is a key responsibility of University Teachers. Effective teaching is based on the teachers' teaching experience and their performance. Teachers' teaching experiences always reflect on their performance (Walke, 2001). As the main functions of the university are to impart knowledge and produce knowledge. For this university teacher is the principal agency who causes the quality of education. So the quality, competence and character of teacher are undoubtedly the most significant. (Isani, 2005)

Effective university teacher was one who quite consistently achieved which either directly or indirectly focused on the learning of the students. Attaining instructional excellence was a complicated process. An effective teacher must have basic command of his subject matter. He must keep abreast of his field and be able to communicate his knowledge effectively to other at the level of comprehension. He must have a acquaintance with psychological principles and to be able to make practical use of them in teaching (Anderson, 2004).

All students have the right to be taught by competent teachers who have competencies about, how students learn? How to achieve the teaching objectives? How to use teaching methods? How to apply teaching models? The use of teaching elements positively, administrative and planning skills, communication skills and finally how to manage the classroom climate. This study is focused on by cases on the thesis that the higher the quality of teachers the higher the quality of education.

\section{OBJECTIVES OF THE STUDY}

Following objectives were focused during the study:

1. to evaluate the indicators of good teaching

2. $\quad$ to examine the institutional policies for valuing the teaching

3. to examine the contribution of teaching towards professional development of teachers

4. to find out institutional efforts for enhancing the professional development of teachers

\section{RESEARCH METHODOLOGY}

Research demands investigation of problems in a scientific way to find out some workable solutions. The main purpose of this study was to analyze the higher quality of teaching and its contribution for acknowledging the university teachers quality and enhancing quality education. The nature of study was descriptive/survey. Hence it was delimited to only federal university teachers. Total population of study consists of five federal public universities. From this population 100 teachers (20 from each university) were selected for sample. The nature of sample was purposive as only good teachers of these universities from each department were selected with the help of student's opinions. For this purpose 5 students from each university were selected for data collection. They were oriented in the selection criteria for good teachers. Following 5 major common teaching competencies were included in the criteria:

- $\quad$ Competencies in to subject and subject area teaching 
- $\quad$ Competencies in teaching and learning process

- $\quad$ Competencies in research work

- Competencies in evaluation techniques

- $\quad$ Competencies in professional behaviour

Firstly $25 \%$ teachers were selected in first phase as sample of good teachers from each university. Then 20 teachers were selected one from each department for final sample of this study making the total 100 best teachers from 5 universities with total population of 1166.

For collection of data two research instruments were used. One unstructured opinionire based upon five major common teaching competencies for students was used for the selection of good teachers. Another questionnaire on three point scale was used for data collection from sampled teachers. For pilot testing questionnaire was distributed among 10 experts. They improved and modified the questionnaire in respect of language, format and meaningfulness. Numbers of items were curtailed from 36 to 25 .

Table 1

\begin{tabular}{|c|c|c|c|c|c|}
\hline $\mathbf{S} \#$ & Statements & Certainly & Seldom & Never & $\begin{array}{l}\text { Mean } \\
\text { Score }\end{array}$ \\
\hline 1. & Facilities needed for proper teaching of courses are available & 14 & 70 & 16 & 1.98 \\
\hline 2. & Methods and techniques of teaching are satisfactory and effective & 4 & 84 & 12 & 1.92 \\
\hline 3. & Teachers update their knowledge through the latest researches & 18 & 76 & 6 & 2.12 \\
\hline 4. & Teacher try to prove themselves as model teachers & 20 & 6 & 74 & 1.46 \\
\hline 5. & $\begin{array}{l}\text { Free and true academic environment is available in universities for every } \\
\text { member of the faculty. }\end{array}$ & 8 & 12 & 84 & 1.32 \\
\hline 6. & $\begin{array}{l}\text { Conferences, seminar, workshops educational field trips and different meetings } \\
\text { are arranged for updating the knowledge of teachers. }\end{array}$ & 6 & 8 & 86 & 1.2 \\
\hline 7. & Teacher's evaluation in the university is done impartially and uniformly & 2 & 6 & 92 & 1.1 \\
\hline 8. & Administration develops sense of integrity and honesty among the teachers & 6 & 6 & 88 & 1.18 \\
\hline 9. & $\begin{array}{l}\text { University authorities of institution give attention to increase the value of } \\
\text { teaching }\end{array}$ & 22 & 70 & 8 & 2.14 \\
\hline 10. & Institution provides the documents which address teaching and learning issues & 4 & 16 & 82 & 1.26 \\
\hline 11. & $\begin{array}{l}\text { Special achievements } \mathrm{n} \text { the areas of teaching appear frequently in institutional } \\
\text { newsletters and institutional publication }\end{array}$ & 2 & 12 & 86 & 1.16 \\
\hline 12. & $\begin{array}{l}\text { Educational policies and practices of institution include the fostering of good } \\
\text { teaching }\end{array}$ & - & 6 & 94 & 1.06 \\
\hline 13. & Good teaching is ranked for the selection of teachers. & 2 & 12 & 86 & 1.16 \\
\hline 14. & $\begin{array}{l}\text { Teachers who do not meet specified criteria for teaching performance being } \\
\text { promoted }\end{array}$ & 12 & 75 & 13 & 1.99 \\
\hline 15. & Research activities are more acknowledge rather than teaching & - & 3 & 97 & 1.03 \\
\hline 16. & $\begin{array}{l}\text { Heads of the departments take responsibility for the promotion of good teaching } \\
\text { in the department and the professional development of staff. }\end{array}$ & 14 & 67 & 19 & 1.95 \\
\hline 17. & $\begin{array}{l}\text { Equal opportunities are available for all teachers about professional } \\
\text { development }\end{array}$ & - & 2 & 98 & 1.02 \\
\hline 18. & $\begin{array}{l}\text { Teachers are encouraged to attend seminars and conferences on teaching in } \\
\text { tertiary education. }\end{array}$ & 2 & 9 & 89 & 1.13 \\
\hline 19. & Teaching evaluation standards are conveyed to the teachers & 4 & 9 & 87 & 1.17 \\
\hline 20. & $\begin{array}{l}\text { Special teaching improvement grants are available at institution faculty or } \\
\text { department level }\end{array}$ & . & 3 & 97 & 1.03 \\
\hline 21. & Awards, Prizes, incentives or forms of recognition are given to good teachers & 2 & 4 & 94 & 1.08 \\
\hline 22. & Research on teaching and learning within a discipline should be ranked & 97 & 2 & 1 & 2.96 \\
\hline 23. & There should be regular public reporting of innovation or excellence in teaching & 95 & 4 & 1 & 2.94 \\
\hline 24. & $\begin{array}{l}\text { Institution should take the initiative for linkage/collaboration national and } \\
\text { international organizations for with enhancing the quality teaching }\end{array}$ & 99 & 1 & & 2.99 \\
\hline 25. & $\begin{array}{l}\text { Heads/Dean should provide equal access to all staff about recent developments } \\
\text { in teaching and learning research and practice. }\end{array}$ & 99 & 1 & - & 2.99 \\
\hline
\end{tabular}

Average mean score $\quad 1.65$ 


\section{RESULTS AND DISCUSSION}

On the basis of Mean Scores of the Table 1 which deals with the opinions of university teachers about the higher the quality of teaching the higher the quality of education. The items of the table focus the indicators of teaching, value of teaching, contribution of teaching and institutional efforts for promoting teaching.

Teaching facilities are not proper. Teaching techniques used are not effective. Teachers do not update their knowledge and they do not prove themselves as model as the average means score against these responses came out 1.86. Anyhow majority responded that free and conducive academic environment is not available. It can safely be concluded that proper teaching need more attention.

Administration does not develop integrity in teachers. Policies of the universities do not foster good teaching. Teaching evaluation criteria are not clear and effective. Grants for good teaching are not provided. The average mean score against these items came out 1.11. Anyhow university authorities gave seldom attention to increase value of teaching.

Good teaching is not given any weight age in selection of teachers. Sub-standard teachers are selected. Research is preferred against the teaching. Teachers are not evaluated impartially. Good teachers are not encouraged with any incentive. As the average means score against these items came out 1.4.

Conferences seminars and workshops are not properly arranged for updating of knowledge. Institutions do not provide documentary guidance for good teaching and newsletters do not cover issues of good teaching. Teachers are not encouraged to participate in seminars and conferences. The average mean score came out 1.16 . Heads of department seldom guide teachers and teachers are not given equal chances for professional development.

Research on teaching should be enhanced and results of such researches should be published. Linkages with national and international institutions should be encouraged equal chances of access to latest academic developments should be provided to all teachers. The average mean score came out 2.97 .

\section{DISCUSSION}

Every discussion on quality education has to relate to teachers. Education is to a large extent a matter of learning process, which takes place through the interaction between teacher and students. When the process works well, real learning will take place. A very natural conclusion is that quality education requires quality teachers. By analyzing the questionnaire, items regarding indicators of good teaching it may be concluded that teachers must prove themselves as good teachers at higher level. For this where the teaching facilities are necessary there the teachers are required to use different teaching strategies and update their knowledge. In accordance with this UNESCO and the ILO (2005) have noted the importance of quality teachers in providing quality education to students and in this way working towards sustainable development. Through their daily work, teachers make a tremendous contribution to sustainable development by building its human foundation-developing a student's capacity and desire to learn.

The analysis of items about the institutional policies regarding valuing the teaching highlights that there is general feeling the quality of teaching at university level has deteriorated rapidly and the present institutional policies has not responded to a large number of inputs made for raising the quality. This conclusion is also strengthened by World Bank Report (1993) that our universities in most of the cases are functioning only as postgraduate colleges and are concentrating mainly on examination oriented teaching. Even the quality of teaching is at the lowest ebb. Our degrees are not acceptable in other countries. In World Bank Report it is stated that using international standards, the degrees of Pakistani Universities, M.A/M.Sc could soon come to the equivalent of secondary school diploma in other countries.

In the context of teaching contribution towards professional development of teachers it is concluded that good teaching does not pay any benefit to teachers except self-satisfaction. This leads the teachers to divert his/her attention towards other beneficial professional activities. This conclusion is also augmented by Buskist (2004), 
Simon (2002), Walker(2001), Poulou (2002) and Mayers (2005) that day by day faculty does not take the teaching seriously. While the best teachers are purposeful peoples who value the teaching and they find their real fulfillment in teaching.

While considering the institutional efforts for enhancing the professional development of teachers it may be concluded that institutions are not playing effective role to enhance the pedagogical skills along with the use of latest instructional technology to make the teaching interesting, effective, interactive, communicative and attractive for raising the quality of higher education. In respect of this conclusion the World Teachers Day (2006) statements says; We, teachers of the World insists that quality education can only be achieved with qualified teachers who have received high-level initial training and have at their disposal pedagogical means to enable them to act as professionals in education.

Keeping in view 1.65 as the average mean score of all the items it can be concluded that the requirements for quality teaching are not available in universities, which leads further to the suggestion that without giving weightage to good teaching in the professional career of the teachers quality education cannot be achieved.

\section{REFERENCES}

1. Anderson, L. W. 2004. Increasing Teacher Effectiveness: UNESCO International Institute for Education Planning, Paris, P. 14.

2. Barnett, R. 1994. the Limit of Competence knowledge, Higher Education and society. Society for research in Higher Education and open University press. Buckingham, U. K. P. 37.

3. Buskist, W. 2004. Rapport-Building: Creating Positive Emotional Contexts for Enhancing teaching and learning. Development and leadership in Higher Education, London.

4. Coleman, B. 1998. Perspectives on Classrooms and Schools. The Open University Press, London, UK. PP. $100,101$.

5. Govt. of Pakistan, 2002. Report of the Task Force on improvement of higher education in Pakistan. Ministry of Education. Islamabad. Pak. P. XIV.

6. Isani, U. A. G. and M. L, Virk. 2005. Higher Education in Pakistan. Historical and Futuristic Perspective. National Book Foundation Islamabad. PP. 256-258.

7. Mayers, D. G. 2005. A Journal on Teaching Tips from Experienced Teachers. Volume 18, No. 3.

8. Misra, B. 2002. Current Issues in Modern Education. Mohit Publications, New Dehli, India. P. 202.

9. $\quad$ McCarty. B. 2003. Shared Insight from University Co-Teaching. USA. P. 36.

10. Poulou, M. 2002. Student Teachers' Perceptions of their Teaching Efficacy, University of Lisbon. P.17.

11. Simon, V. 2002. An Article on perceived problems of beginning Teachers, Review of Educational Research, New Mexico. PP. 143-178.

12. UNESCO, 1998. Higher education in the Twenty-first Century, Vision and action, Paris. P. 3, 46, 51, 53, 57.

13. UNESCO. 1998. Higher Education in the Twenty-First Century Vision and Action, Paris. Pp. 35-42.

14. UNESCO, 1998 World Conference on Higher Education. Paris, P-11

15. UNESCO/ILO (2005) World Teachers Day. Paris, P-58.

16. Walker, M. 2001. Reconstructing Professionalism in University Teaching, Buckingham: Society for research in higher education and open university press, Buckingham. P.104.

17. World Bank Report, 1993. Improving Higher Education in Developing Countries, the World Bank, Washington, D. C. P. 4.

18. Zaman, T. U. 1998. Higher education. Faculty of Education teacher Education Department Allama Iqbal Open University, Islamabad pp. 2, 4.

19. www.atl.org.uk/international /WTD2006.aspdt 11/5/7 
NOTES 